\title{
SUPERIOR VERSUS ANTERO-INFERIOR PLATING OF CLAVICLE FRACTURES- A RETROSPECTIVE STUDY AT OUR INSTITUTION
}

\author{
Subhasis Ranjan Mitra1, Rajiv Roy²
}

${ }_{1}^{1}$ Associate Professor, Department of Orthopaedic Surgery, Calcutta National Medical College, Kolkata, West Bengal, India. ${ }_{2}^{2}$ Associate Professor, Department of Orthopaedic Surgery, Calcutta National Medical College, Kolkata, West Bengal, India. ABSTRACT

\section{BACKGROUND}

ORIF of displaced clavicle fractures by plating has proved to be reliable and reproducible with high union rates and a low rate of associated complications. Decision regarding whether to place the plate superiorly or antero-inferiorly is debatable.

\section{MATERIALS \& METHODS}

A retrospective study of 24 patients is mentioned here. Fourteen patients (10 males and 4 females) were operated with superior plating and in rest 10 patients ( 9 males and 1 female), fixation was done by antero-inferior plating.

\section{RESULTS}

We did not find any significant difference between the two groups with regard to age, sex, involved side, or with use of tobacco (Table 1). No significant difference was found in either fracture union, in any group ( $p=0.41$, Table 2), or outcome of plate length used $(p=0.68$, Table 2). Duration of surgery in the antero-inferior plating was more in comparison to the other group ( $p=0.68$, Table 2). There were 3 cases of implant removal, and malunion in 1 case, only in the superior plating group. There were no nonunion or any case of infection in any of the groups. Similar results have been shown by both superior and antero-inferior plating of the clavicle in this study (statistical data provided in Tables 1 to 3 ).

\section{CONCLUSION}

Both methods of fixation were reliable and safe. Complication rates were a bit higher in the group with superior plate placement.

\section{KEY WORDS}

Clavicle Fractures, Antero-Inferior Plating, Superior Plating, Open Reduction Internal Fixation (ORIF)

HOW TO CITE THIS ARTICLE: Mitra SR, Roy R. Superior versus antero-inferior plating of clavicle fractures- a retrospective study at our institution. J. Evolution Med. Dent. Sci. 2019;8(09):626-629, DOI: 10.14260/jemds/2019/138

\section{BACKGROUND}

Approximately $3.5 \%$ of all fractures are clavicle fractures in Orthopaedics practice, and are very common 1,2 . About 80 percent of clavicle fractures involve the middle third of the clavicle.1,2

Traditionally these fractures were treated conservatively with a brace or sling with good results (Union rates approximating 80.1\%).3,4 However with increase in industries and advent of high-speed vehicles and a fast transport system, there is an increasing incidence of high velocity trauma. Conservative (Non-operative) means of treatment in these cases frequently end up in a non-union, symptomatic mal union or an odd cosmetic deformity. ${ }^{5-8}$ As a result of increased rates of complications there has been an increasing trend towards operative fixation (Figure 1).

Clavicle fractures can be fixed with different types of plates, threaded screws and TENS. We selected plate and screw constructs, because of good predictable outcomes and low non-union rates.8,9

'Financial or Other Competing Interest': None.

Submission 23-10-2018, Peer Review 17-02-2019,

Acceptance 22-02-2019, Published 04-03-2019.

Corresponding Author:

Dr. Rajiv Roy,

Associate Professor

Department of Orthopaedic Surgery,

Calcutta National Medical College,

Flat B4/11, East Enclave Co-op Housing

No.2, Major Arterial Road, Action Area 1

New Town, Kolkata -700156, West Bengal, India.

E-mail:drrroy@gmail.com

DOI: $10.14260 /$ jemds/2019/138
MATERIALS AND METHODS

This retrospective study was conducted to compare, the duration of surgery, risks and complications associated, average healing or union rates and time, in two methods of fixation (Superior and antero-inferior plating) in mid shaft clavicle fractures, and to determine a preferred plate position.

The study was conducted in the Department of Orthopaedic Surgery, Calcutta National Medical College, between August 2015 and September 2017, after approval from the ethics committee. Study population comprised of Twenty-four consecutive patients (Who met the inclusion and exclusion criteria), amongst those who were treated operatively for displaced clavicle fractures, within this period, at our Institution, by open reduction and internal fixation (ORIF) with plates and screws, irrespective of fracture comminution. Of the twenty-four patients, in 14 patients, plates were placed in the superior surface and in the rest 10 , plates were placed in the antero-inferior surface, according to surgeons' preference during the procedure, for a stable construct. Of the 14 patients in whom the plates were placed in the superior surface there were 4 females and in the other group there was 1 female.

\section{Inclusion Criteria}

1. Selected patients were between 20-60 yrs of age, with displaced mid shaft clavicle fracture without neurovascular compromise.

2. All patients followed for 12 months or more, in the postoperative period. 


\section{Exclusion Criteria}

1. Previous surgery of same clavicle.

2. Initial presentation with a non-union.

3. Open fractures.

4. Associated major long bone fracture

5. Associated medical co-morbidities.

\section{Data Collection}

Data was collected for each patient regarding

1. Age.

2. Sex.

3. Side involved.

4. Tobacco use.

5. Length of plate used.

6. Duration from initial insult to time of surgery.

7. Duration of surgery.

8. Time to achievement of union, Union was defined by radiographic evidence of healing on 3 cortices and absence of any tenderness at fracture site.

\section{Operative Procedure and After Care}

All the patients were operated under general anaesthesia. Routinely, following draping all the patients were administered $1.5 \mathrm{gm}$ cefuroxime, through the intravenous route, after skin testing. The approach used was standard approach to the clavicle. With the head end elevated by breaking the table, and placing a sand bag between the ipsilateral shoulder blade and the spine. Maintaining strict asepsis protocols, incision was given over the clavicle, through the desired length, after tracing the clavicle laterally from the sternal notch located in the midline. The subcutaneous tissue and the platysma were incised along the same line to reach the sub cutaneous surface of the clavicle. Meticulous haemostasis was achieved by cauterizing the bleeders. The soft tissues were gently stripped from the epi periosteal plane of the clavicle, using a small periosteum elevator, to expose the superior or antero-inferior surface. The fracture ends were cleared of clots. The fractures were then reduced, held with reduction clamps, and plates were placed either on the superior or antero-inferior surface, after contouring the plates, if required. Throughout the steps the underlying tissues were protected using small to medium sized Hohmann retractors, subperiosteally, especially during antero-inferior plate placement. The plates were then fixed to the bone with appropriate size and no. of screws, after carefully drilling the holes gently with drill heads, protected through sleeves, and taking utmost care when drilling the far cortex, to minimize over penetration, from superior to antero-inferior direction (In cases of superiorly placed plates), to avoid injury to the underlying major vessels and the brachial plexus. With the fracture fixed the wound was copiously lavaged with sterile normal saline. The platysma was repaired with delayed absorbable sutures and the skin closed and covered with sterile packs.

The patients were discharged on the $4^{\text {th }}$ post-operative day, after wound inspection, and the skin sutures removed on the $14^{\text {th }}$ post-operative day. Thereafter patients were followed-up at 4 weekly intervals. Information regarding pain at the site, implant prominence, subsequent malalignment, numbness at incision site or paraesthesia, noted, and radiological assessment done.

\section{Statistical Analysis}

Data were analysed using SPSS (Statistical Package for Social Scientists) version 20.0, IBM, Armonk, New York, USA. Unpaired T-test and Chi-square test were applied at 5\% significance level.

\section{RESULTS}

Out of the total 24 patients who underwent surgery (ORIF), 14 underwent superior plating and 10 underwent anteroinferior plating. Four patients amongst the 14 who underwent superior plating and 1 patient amongst the other group were females.

No statistically significant difference was noted between the two groups with regard to age, sex, involved side, or with use of tobacco ( $\mathrm{p}$ values $>0.05$, Table 1 ). Both groups had similar intervals prior to surgery, again of no statistical significance ( $p=0.07$ Table 2). Evidence of radiographic union was achieved at a similar time for both the groups following surgery, not a statistically significant variance $(p=0.41$ Table 2). Plate length did not affect the outcome ( $p=0.68$ Table 2$)$.

Duration of surgery for Antero-inferior plating was more as compared to Superior plating, but the variance is most probably a chance finding, rather than a statistically significant variance $(\mathrm{p}=0.68$, Table 2$)$. Implant removal following implant prominence had to be done in 3 cases and malunion occurred in 1 case, only in superior plating group, and thus could not be compared with the other group. In our study we did not have any non-union or any case of infection in any of the groups. Similar results have been shown by both superior and antero-inferior plating of the clavicle in this study (Statistical data provided in Tables 1 to 3).
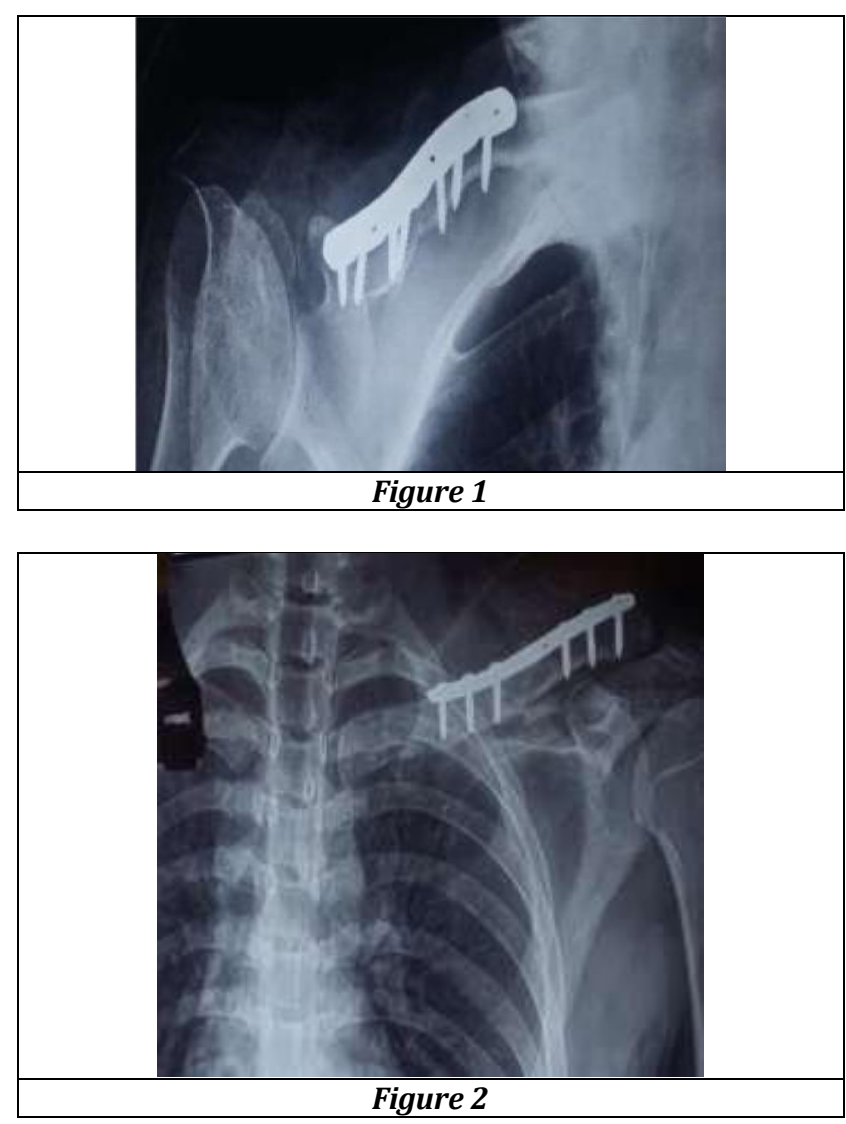


\begin{tabular}{|c|c|c|c|c|}
\hline \multicolumn{2}{|c|}{ Demographics } & $\begin{array}{l}\text { Superior } \\
\text { Plating } \\
\text { Group } \\
(\mathrm{n}=14)\end{array}$ & $\begin{array}{c}\text { Antero- } \\
\text { Inferior } \\
\text { Plating Group } \\
(n=10)\end{array}$ & $\mathbf{p}$ \\
\hline \multicolumn{2}{|c|}{$\begin{array}{c}\text { Age (Mean } \pm \text { SD) } \\
\text { yrs. }\end{array}$} & $37.36 \pm 11.17$ & $39.5 \pm 11.04$ & 0.64 \\
\hline \multirow{2}{*}{$\begin{array}{c}\text { Sex } \\
\text { No. (\%) }\end{array}$} & Male & $10(71.43)$ & $9(90)$ & \multirow{2}{*}{$\begin{array}{l}0.35 \text { (Yates } \\
\text { Correction) }\end{array}$} \\
\hline & Female & $4(28.57)$ & $1(10)$ & \\
\hline \multirow{2}{*}{$\begin{array}{c}\text { Side } \\
\text { Injured } \\
\text { No. (\%) }\end{array}$} & Right & $8(57.14)$ & $4(40)$ & \multirow{2}{*}{$\begin{array}{l}0.41 \text { (Yates } \\
\text { Correction) }\end{array}$} \\
\hline & Left & $6(42.86)$ & $6(60)$ & \\
\hline \multirow{2}{*}{$\begin{array}{l}\text { Tobacco } \\
\text { Use } \\
\text { No. }(\%)\end{array}$} & Yes & $7(50)$ & $5(50)$ & \multirow{2}{*}{$\begin{array}{l}0.68 \text { (Yates } \\
\text { Correction) }\end{array}$} \\
\hline & No & $7(50)$ & $5(50)$ & \\
\hline
\end{tabular}

\begin{tabular}{|c|c|c|c|}
\hline Data & $\begin{array}{c}\text { Superior } \\
\text { Plating Group } \\
\text { ( n=14) } \\
\text { Mean } \pm \text { SD }\end{array}$ & $\begin{array}{c}\text { Antero-Inferior } \\
\text { Plating Group } \\
\text { (n= 10) } \\
\text { Mean } \pm \text { SD }\end{array}$ & $\mathbf{p}$ \\
\hline $\begin{array}{c}\text { Avg. Time from } \\
\text { Injury to Surgery } \\
\text { (Days) }\end{array}$ & $4.78 \pm 1.52$ & $3.6 \pm 1.43$ & 0.07 \\
\hline $\begin{array}{c}\text { Duration of Surgery } \\
\text { (minutes) }\end{array}$ & $60 \pm 6.20$ & $90 \pm 7.07$ & 0.68 \\
\hline $\begin{array}{c}\text { Length of Plate (No. } \\
\text { of Holes) }\end{array}$ & $7.4 \pm 0.56$ & $7.2 \pm 0.79$ & 0.47 \\
\hline $\begin{array}{c}\text { Time to Union } \\
\text { (weeks) }\end{array}$ & $16.57 \pm 2.98$ & $15.8 \pm 2.74$ & 0.41 \\
\hline \multicolumn{2}{|c|}{ Table 2. Comparative Operative Data } & \\
\hline
\end{tabular}

\begin{tabular}{|c|c|c|}
\hline \multirow{2}{*}{ Data } & $\begin{array}{c}\text { Superior Plating } \\
\text { Group ( }=14)\end{array}$ & $\begin{array}{c}\text { Antero-Inferior } \\
\text { Plating Group (n= 10) }\end{array}$ \\
\cline { 2 - 3 } & No. (\%) & No. (\%) \\
\hline Malunion & $1(7.14)$ & $0(0.00)$ \\
\hline Implant Removal & $3(21.42)$ & $0(0.00)$ \\
\hline \multicolumn{2}{|c|}{ Table 3. Comparison of Complications } \\
\hline
\end{tabular}

\section{DISCUSSION}

Over the last few decades the management of clavicle fractures have evolved drastically. A resurgence has occurred favouring operative fixation for displaced clavicle midshaft fractures, after literatures reporting poor outcomes by nonoperative management of certain fracture geometries. 5,10,11 Of various methods of operative fixation available, plate fixation of displaced clavicle fractures is found to be good and reproducible, having union rates from $94 \%$ to $100 \%$, and low rate of complications.6-8,12-15 Decision regarding ideal placement of the plate superiorly or antero-inferiorly is debatable. The authors found similar union rates and did not find any difference in the major parameters in any of the groups.

Healing rates in this study are similar to that of current literature ( 94 to $100 \%$ ), but the time of healing in our study was more than 15 weeks, compared to less than 14 weeks reported in literature.11,13,16 This might have been due to the follow-up schedule of our study. Studies conducted by Partal et al ${ }^{11}$ and Favre et al ${ }^{17}$ shows antero-inferior plating to be a more stable construct. Perioperative complications between the 2 groups were similar with no acute wound healing issues. Sinha et $\mathrm{al}^{18}$ in a study found that the major vessels are most prone to injury with a superior to inferior screw trajectory at the mid shaft of clavicle, though in our retrospective study we did not face any such issues. However, placement of plate in any of the positions, carries the risk of iatrogenic injuries to the neurovascular bundles, and neither position had significantly decreased risks. 18,19,20

This study had several limitations. The sample size was small, implants were surgeon selected, without randomization, and differing fracture geometries not brought into consideration in this study by the authors retrospectively. The other weakness is the follow-up length: it being unknown whether these cases can become more symptomatic with passage of time, or a differing trajectory to recovery occurs with either position of the plate.

Despite of several weaknesses, the strength of the study merits discussion. This was a study at our Institution to objectively study and compare two fixation methods, though in a small group. The surgeries were performed by 2 trained and experienced surgeons in the field of trauma surgeries, better than a single surgeon review.

\section{CONCLUSION}

As per current data, both superior plating and antero-inferior plating, are safe methods of management of displaced clavicle fractures. The largest difference found in this study was to be a significantly higher rate of patients reporting implant prominence, in the superior plating group, leading to removal of the implant, which could not be statistically corroborated due to absence of any incidence of implant removal in the other group. The other difference found, though not statistically significant, was the shorter duration of surgery, in the superior plating group. Further research, with larger number of subjects, is required because fixation of clavicle fractures is becoming standard of care for particular fractures ${ }^{6}$. Future prospective studies, with randomized analyses, preferably multicentric studies, may help in determining the preferred plate positioning.

\section{ACKNOWLEDGEMENTS}

We acknowledge Dr. Shuvankar Mukherjee, Assistant Professor of Community Medicine, of our Institution, in guiding us through the statistical calculations and analyses.

\section{REFERENCES}

[1] Nordqvist A, Petersson C. The incidence of fractures of the clavicle. Clinical Orthop Rel Res 1994;(300):12732.

[2] Neer CS II. Fractures of the Clavicle. In: Rockwood CA Jr, Green DP, eds. Fractures in adults. 2nd edn. Philadelphia, PA: Lippincott: 1984: p. 707-13.

[3] Neer CS II. Nonunion of clavicle. J Am Med Assoc 1960;172(10):1006-11.

[4] Rowe CR. An atlas of anatomy and treatment of midclavicular fractures. Clin Orthop Relat Res 1968;(58):29-42.

[5] McKee MD, Pedersen EM, Jones C, et al. Deficits following non-operative treatment of displaced midshaft clavicular fractures: a meta-analysis of randomized clinical trials. J Bone Joint Surg Am 2006;88(1):35-40.

[6] McKee RC, Whelan DB, Schemitsch EH, et al. Operative versus non-operative care of displaced midshaft clavicular fractures: a meta-analysis of randomized clinical trials. J Bone Joint Surg Am 2012;94(8):67584. 
[7] Canadian Orthopaedic Trauma Society. Non-operative treatment compared with plate fixation of displaced midshaft clavicular fractures. A multicentre, randomized clinical trial. J Bone Joint Surg Am 2007;89(1):1-10.

[8] Kulshreshtha V, Roy T, Audige L. Operative versus non-operative care of displaced midshaft clavicular fractures: a prospective cohort study. J Orthop Trauma 2011;25(1):31-8.

[9] Robinson CM, Court-Brown CM, McQueen MM, et al. Estimating the risk of non-union following nonoperative treatment of a clavicular fracture. J Bone Joint Surg Am 2004;86-A(7):1359-65.

[10] Hill JM, McGuire MH, Crosby LA. Closed treatment of displaced middle-third fractures of clavicle gives poor results. J Bone Joint Surg Br 1997;79(4):537-9.

[11] Partal G, Meyers KN, Sama N, et al. Superior versus anteroinferior plating of the clavicle revisited: a mechanical study. J Orthop Trauma 2010;24(7):420-5.

[12] Jones CB, Sietsema DL, Ringler JR, et al. Results of anterior-inferior 2.7-mm dynamic compression plate fixation of midshaft clavicular fractures. J Orthop Trauma 2012;0:1-4.

[13] Zlowodski M, Zelle BA, Cole PA, et al. Treatment of acute midshaft clavicle fractures: systematic review of 2144 fractures: on behalf of the Evidence-Based Orthopaedic Trauma Working Group. J Orthop Trauma 2005;19(7):504-7.
[14] McKee MD, Seiler JG, Jupiter JB. The application of limited contact dynamic compression plate in the upper extremity: an analysis of 114 consecutive cases. Injury 1995;26(10):661-6.

[15] Chen CH, Chen JC, Wang C, et al. Semitubular plates for acutely displaced mid-clavicular fractures: a retrospective study of 111 patients followed for 2.5 to 6 yrs. J Orthop Trauma 2008;22(7):463-6.

[16] Collinge C, Devinny S, Herscovici D, et al. Anterior inferior plate fixation of middle third fractures and non-unions of the clavicle. J Orthop Trauma 2006;20(10):680-6.

[17] Favre P, Kloen P, Helfet DL, et al. superior versus anteroinferior plating of the clavicle: a finite element study. J Orthop Trauma 2011;25(11):661-5.

[18] Sinha A, Edwin J, Sreeharsha B, et al. A study to define safe zones for drilling during plating of clavicle fractures. J Bone Joint Surg Br 2011;93(9):1247-52.

[19] Werner SD, Reed J, Hanson T, et al. Anatomic relationships after instrumentation of the midshaft clavicle with $3.5-\mathrm{mm}$ reconstruction plating: an anatomic study. J Orthop Trauma 2011;25(11):65760.

[20] Lo EY, Eastman J, Tseng S, et al. Neurovascular risks of anteroinferior clavicular plating. Orthopedics 2010;33(1):21. 